\title{
Pathological Investigations on Galilee Tilapia (Sarotherodon galilaeus) Following Chronic Exposure to Cadmium Chloride
}

\section{Hossam G Tohamy ${ }^{1}$ and Ramy M Shourbela ${ }^{2 *}$}

${ }^{1}$ Department of Pathology, Faculty of Veterinary Medicine, Alexandria University, Egypt

${ }^{2}$ Department of Animal Husbandry and Animal Wealth Development, (Fish Breeding and Production) Faculty of Veterinary Medicine, Alexandria University, Egypt

\begin{abstract}
The morphopathological alterations of chronic cadmium (Cd) toxicity in Sarotherodon galilaeus were studied 126 fish were used to determine 96 hrs LC $_{50}$ of cadmium chloride, the obtained result was $28.3 \mathrm{mg} / \mathrm{L}$. Forty-eight fish were used to induce chronic toxicity, twenty-four fish were exposed to $2.83 \mathrm{mg} / \mathrm{L}$ cadmium chloride for 8 weeks and other fish as control. Gills, hepatopancreas, posterior kidney and spleen were the most affected organs during chronic exposure. Eosinophilic granular cells (EGCs) infiltration and goblet cells hyperplasia in tips of primary lamellae, lamellar lifting, lamellar necrosis and Proliferative interlamellar hyperplasia with fusion in gills, hydropic degeneration and necrosis of the hepatic cells, hemorrhage and necrotic renal tubules and splenic necrosis and depletion of lymphocytes were recorded as histopathological changes.
\end{abstract}

Keywords: Morphopathological; Cadmium; Sarotherodon galilaeus; Hyperplasia; Depletion

\section{Introduction}

Freshwater acquires contaminated with a large number of pollutants and it has become a matter of major concern allover the world $[1,2]$. Among pollutants and metals are of particular interest because of their varied effects and the range of concentrations which may cause toxic effects to fish [2]. Many studies are available that demonstrate heavy metal toxicity in fish $[3,4]$. Cadmium has no biological function in living organisms. It widely used in fertilizer, automotive, dye, plastics and synthetic fiber industries and battery production [5]. Even small amounts of this metal entered into aquatic systems, results in accumulation in various tissues, changes in metabolic, physiologic and biochemical parameters and death in sensitive species. Cadmium exposure may lead to the results of some pathophysiological damages in various tissues including liver [6], brain [7] and kidney [8]

One of the common and commercially important cultured tilapia species is Sarotherodon galilaeus (S. galilaeus) [9] but Limited information is available about the morphopathological alterations of chronic cadmium toxicity in this fish. However, some authors are applying some studies of cadmium toxicity on another tilapia species as in Oreochromis niloticus $[10,11]$ and Oreochromis mossambicus [12]. More as there were no available references concerning the histopathological alterations of chronic cadmium toxicity in this economic species. Ultimately, more research is needed to determine 96 hrs LC $_{50}$ of cadmium chloride in such species and morphopathological alterations of chronic cadmium toxicity of this species. So the aim of this study is to determine the $\mathrm{LC}_{50}$ of cadmium chloride and to assess the morphopathological alterations of chronic cadmium toxicity for S. galilaeus.

\section{Materials and Methods}

\section{Experimental fish}

Fish used for the experiments were collected from local lake and were acclimatized for two weeks before beginning of the experiments in glass aquaria $(90 \times 50 \times 35 \mathrm{~cm})$. These aquaria are supplied with chlorine-free tap water. Oxygen supply was maintained in each aquarium using an electric air pumping compressors. Apparently healthy $S$. galilaeus fish were selected for the study having a mean weight $41.4 \pm 3.4 \mathrm{gm}$. The experiments were performed under natural light and ambient temperature $\left(25 \pm 1^{\circ} \mathrm{C}\right)$ and $\mathrm{PH}(7.3 \pm 0.3)$. Fish were fed on a commercial fish diet containing $25 \%$ crude protein at $3 \%$ of body weight daily.

\section{Cadmium chloride}

Cadmium chloride (99\% purity) was obtained from El-Nasr Chemical Company (Cairo, Egypt) and prepared in aquatic solution to provide the required concentrations of cadmium.

\section{Determination of 96 hrs $\mathrm{LC}_{50}$ of cadmium chloride}

126 fish (S. galilaeus) were used in this experiment. Fish were divided into seven groups having eighteen fish in each. These groups were exposed to $0,15,20,25,30,35$ and $40 \mathrm{mg} / \mathrm{L}$ cadmium chloride up to $96 \mathrm{hrs}$. Water and $\mathrm{CdCl}_{2}$ were renewed daily. The calculation of $\mathrm{LC}_{50}$ is done according to the formula of Stephan [13].

\section{Chronic cadmium chloride toxicity}

Forty-eight fish (S. galilaeus) were randomly divided into 2 equal groups having twenty-four fish in each; one group as a control group (no cadmium chloride) and the other group exposed to $1 / 10(2.83 \mathrm{mg} /$ $\mathrm{L})$ of $\mathrm{LC}_{50}$ cadmium chloride that determined in the first experiment. The water and cadmium chloride were renewed daily for eight weeks. The clinical signs and mortality were recorded along the experimental period. Weekly necropsy was performed for 3 randomly selected fish from each group up to eight weeks.

\section{Histopathological studies}

Tissue specimens (gills, hepatopancreas, posterior kidney and

*Corresponding author: Ramy M Shourbela, Department of Animal Husbandry and Animal Wealth Development, (Fish Breeding and Production) Faculty of Veterinary Medicine, Alexandria University, Egypt, Tel: +20 3 5921675; E-mail: ramy_aqua@yahoo.com

Received August 20, 2016; Accepted September 13, 2016; Published September 15,2016

Citation: Tohamy HG, Shourbela RM (2016) Pathological Investigations on Galilee Tilapia (Sarotherodon galilaeus) Following Chronic Exposure to Cadmium Chloride. J Aquac Res Development 7: 446. doi: 10.4172/2155-9546.1000446

Copyright: @ 2016 Tohamy HG, et al. This is an open-access article distributed under the terms of the Creative Commons Attribution License, which permits unrestricted use, distribution, and reproduction in any medium, provided the original author and source are credited. 
Citation: Tohamy HG, Shourbela RM (2016) Pathological Investigations on Galilee Tilapia (Sarotherodon galilaeus) Following Chronic Exposure to Cadmium Chloride. J Aquac Res Development 7: 446. doi: 10.4172/2155-9546.1000446

Page 2 of 4

\begin{tabular}{|c|c|c|c|c|c|c|c|c|}
\hline \multirow{2}{*}{ Group } & \multirow{2}{*}{$\begin{array}{l}\mathrm{CdCl}_{2} \\
\mathrm{mg} / \mathrm{L}\end{array}$} & \multirow{2}{*}{ No. of fish } & \multicolumn{6}{|c|}{ Number of dead fish } \\
\hline & & & $24 \mathrm{hrs}$ & $48 \mathrm{hrs}$ & $72 \mathrm{hrs}$ & 96 hrs & Overall death within $96 \mathrm{hrs}$ & Mortality \% \\
\hline GP1 & 0 & 18 & 0 & 0 & 0 & 0 & 0 & 0 \\
\hline GP2 & 15 & 18 & 0 & 0 & 0 & 0 & 0 & 0 \\
\hline GP3 & 20 & 18 & 0 & 0 & 0 & 0 & 0 & 0 \\
\hline GP4 & 25 & 18 & 0 & 4 & 2 & 2 & 8 & 44.44 \\
\hline GP5 & 30 & 18 & 2 & 3 & 4 & 2 & 11 & 61.11 \\
\hline GP6 & 35 & 18 & 5 & 4 & 4 & 3 & 16 & 88.89 \\
\hline GP7 & 40 & 18 & 7 & 6 & 5 & 0 & 18 & 100 \\
\hline
\end{tabular}

$\mathrm{LC}_{50}=(\mathrm{AB})^{1 / 2}$

$A=$ the minimum test material concentration that cause $100 \%$ death

$B=$ the maximum test material concentration that cause $100 \%$ viability

Table 1: Mortality pattern during the estimation of $96 \mathrm{hrs} \mathrm{LC}_{50}$.

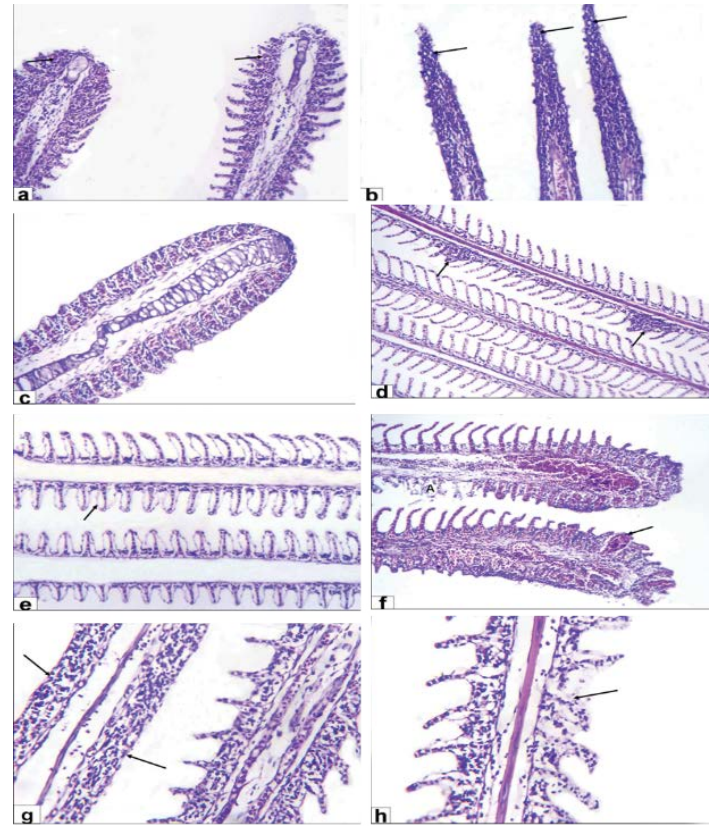

Figure 1: Photomicrograph of $S$. galilaeus gills exposed to $2.83 \mathrm{mg} / \mathrm{L} \mathrm{CdCl}_{2}$ and stained with HE. (a): Eosinophilic granular cells (EGCs) infiltration in tips of primary lamellae (arrows, X200) during $1^{\text {st }}$ week. (b): Hyperplasia of the goblet cells in the tips of primary lamellae (arrows, X200) during $2^{\text {nd }}$ week. (c): Filamentous clubbing (X200) during $3^{\text {rd }}$ week. (d): Multifocal fusion of secondary lamellae (arrows, X200) during $4^{\text {th }}$ week. (e): Lamellar lifting (arrow, X200) during $5^{\text {th }}$ week. (f): Lamellar necrosis (A) and telangiectasis (arrow, X200) during $6^{\text {th }}$ week. (g): Interlamellar epithelial hyperplasia with lamellar fusion (arrows, X400)

$7^{\text {th }}$ week. (h): Lamellar necrosis (arrow, X400) during $8^{\text {th }}$ week.

spleen) were rapidly fixed in $10 \%$ formalin-saline solution. The fixed specimens were processed through the conventional paraffin embedding technique. Paraffin blocks were prepared, from which 5 microns thick sections were obtained. These sections were stained by Hematoxyline and Eosin (HE) [14].

\section{Results}

\section{Determination of 96 hrs $\mathrm{LC}_{50}$ of cadmium chloride in $S$. galilaeus}

The $96 \mathrm{hrs}-\mathrm{LC}_{50}$ of cadmium chloride toxicosis in S. galilaeus is summarized in Table 1. The result showed that the $96 \mathrm{hrs}-\mathrm{LC}_{50}$ of cadmium chloride in S. galilaeus was $28.3 \mathrm{mg} / \mathrm{L}$.

\section{Chronic cadmium chloride toxicity}

Clinical signs and post-mortem findings: The most obvious signs in all toxicated fish were respiratory manifestation in the form of gasping, rapid operculum movements and collecting at the oxygen source began during the first week and extended to the end of an experiment with more obvious signs at the last three weeks. No mortalities were recorded during the chronic experiment. Internally, congestion of the gills, hepatopancreas, kidney and spleen was evident. The gills exhibited dark red spots alternative with another pale area.

\section{Histopathological lesions}

Gills: The noticeable lesions during $1^{\text {st }}$ and $2^{\text {nd }}$ week were EGCs infiltration and the goblet cells hyperplasia in the tips of primary lamellae (Figures 1a and 1b). interlamellar epithelial hyperplasia at the tips of gill filaments lead to filamentous clubbing (Figure 1c) and at the secondary lamellae lead to multifocal fusion of the secondary lamellae (Figure 1d) were noticed during $3^{\text {rd }}$ and $4^{\text {th }}$ week. Lamellar lifting where separation of the surface epithelium of secondary lamellae from capillary beds by edema (Figure 1e) and lamellar telangiectasis due to rupture of retaining pillar cells (Figure 1f) were appeared during $5^{\text {th }}$ and $6^{\text {th }}$ week. Lamellar fusion (Figure 1g) and lamellar necrosis (Figure 1h) were detectable during $7^{\text {th }}$ and $8^{\text {th }}$ week.

Hepatopancreas: The encountered lesions in the hepatopancreas were congestion of the pancreatic acini and the hepatic sinusoids (Figure 2a) during $1^{\text {st }}$ week beside sever hydropic degeneration of the hepatocytes where the cytoplasm is replaced by clear fluids and the nucleus not affected either in shape or location (Figure $2 b$ ), and activation of melanomacrophage centers (Figure 2c) during $3^{\text {rd }}$ and $4^{\text {th }}$ week. In late stage of the experiment the observed lesion was necrosis of the pancreatic acini (Figure 2d) and necrosis of the hepatocytes (Figures $2 \mathrm{e}$ and 2f).

Posterior kidney: histopathological findings in posterior kidney during first two weeks of cadmium chloride toxicity were congestion of blood vessels and activation of MMCs (Figure 3a). During $4^{\text {th }}$ week the posterior kidney exhibited extravasations of erythrocytes from the blood vessel (Figure 3b). The posterior kidney showed intraepithelial hyaline droplets in proximal convoluted tubules replaced the necrotic lining epithelium (Figure $3 \mathrm{c}$ ) during $6^{\text {th }}$ week beside tubular necrosis (Figure 3d) during late stage of the experiment.

Spleen: The microscopic lesions of the spleen consisted of enlargement and activation in MMCs (Figure 4a) and the melanophores appeared heavily loaded with dark brown melanin pigment (Figure 4b) that was encountered all over the experiment. Multifocal lymphocytic cell necrosis and depletion was the most detected lesion in late period of the experiment (Figure 4c).

\section{Discussion}

Cadmium is one of the most toxic heavy metals in water environment 
Citation: Tohamy HG, Shourbela RM (2016) Pathological Investigations on Galilee Tilapia (Sarotherodon galilaeus) Following Chronic Exposure to Cadmium Chloride. J Aquac Res Development 7: 446. doi: 10.4172/2155-9546.1000446

which affects aquaculture and fish health [11]. Cadmium is toxic at low concentrations to all life, including plants, fish, birds, mammals [1517]. In this study, the $\mathrm{LC}_{50}$ of $\mathrm{CdCl}_{2}$ was $28.9 \mathrm{mg} / \mathrm{L}$, showing that $S$. galilaeus is more sensitive to acute cadmium toxicity than other tilapia species as showing in previous studies, $\mathrm{LC}_{50}$ of cadmium chloride in O. niloticus was $40.5 \mathrm{mg} / \mathrm{L} \mathrm{[10]} \mathrm{and} 80 \mathrm{mg} / \mathrm{L}$ in O. mossambicus [18]. Therefore, histopathological lesions in fish tissue can be used as a tool in reviling the direct toxic effects of chemicals in target organs [19], because they reflect the damage caused by period and severity of exposure to toxic element and the tissue adaptive capacity [20]. In the $10 \%$ of $\mathrm{LC}_{50}$ group the histopathological changes were existed mainly in the gills, hepatopancreas, posterior kidney and spleen.

Gill epithelium is the primary target organ for aqueous exposure, which suffers an acute edema and epithelial lifting during exposure. Edema with lifting of lamellar epithelium could be serve as a mechanism of defense, because separation epithelial of the lamellae

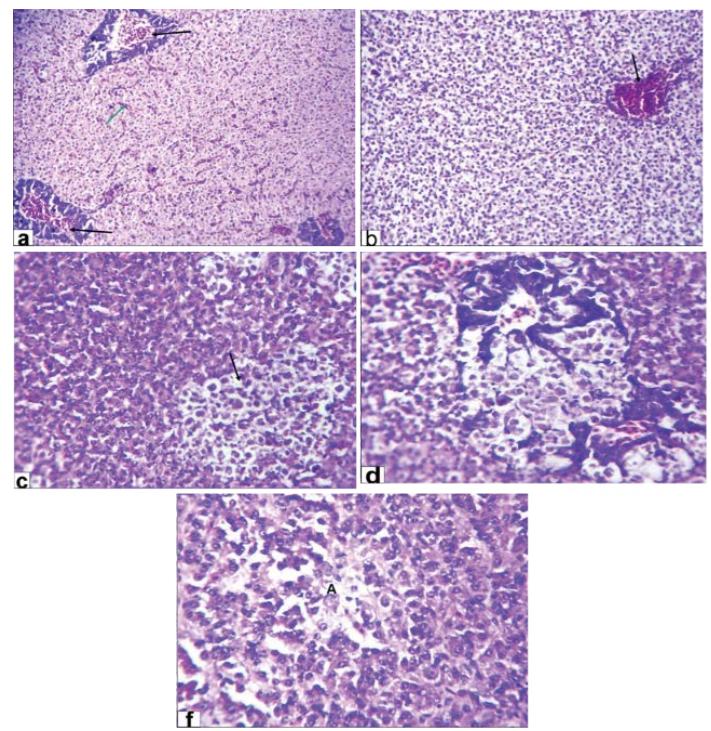

Figure 2: Photomicrograph of S. galilaeus Hepatopancreas exposed to 2.83 $\mathrm{mg} / \mathrm{L} \mathrm{CdCl}{ }_{2}$ staining by $\mathrm{HE}(\mathrm{a})$ : Congestion of pancreatic acini (black arrows) and hepatic sinusoids (green arrow, X200) during $1^{\text {st }}$ week. (b): Sever hydropic degeneration of hepatocytes and congestion of blood vessel (arrow, X200) during $3^{\text {rd }}$ week. (c): Activation of MMCs (X200) during $4^{\text {th }}$ week. (d): Necrosis of pancreatic acini $(X 400)$ during $6^{\text {th }}$ week. (f): Necrosis of the hepatocytes (A, $\mathrm{X} 400$ ) during $7^{\text {th }}$ week.

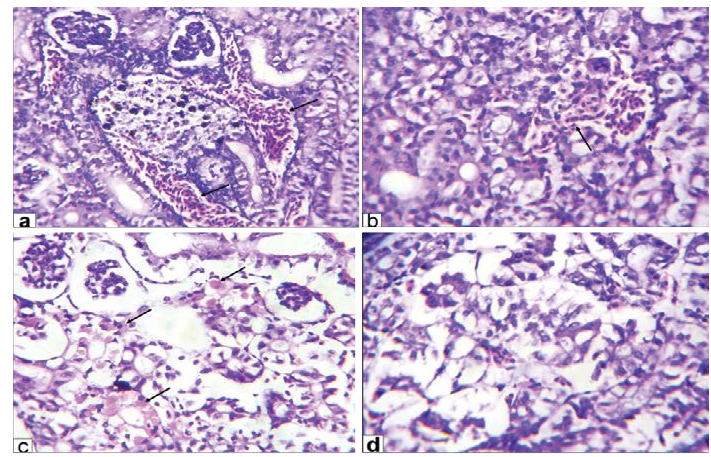

Figure 3: Photomicrograph of S. galilaeus posterior kidney exposed to 2.83 $\mathrm{mg} / \mathrm{L} \mathrm{CdCl}$ and staining by HE. (X250) (a): Congestion of blood vessels (arrows) and activation of melanomacrophage centers (MMCs) during $2^{\text {nd }}$ week. (b) Hemorrhage (arrow) during $4^{\text {th }}$ week. (c): Homogenous structure-less esinophilic material replaced necrotic lining epithelium of the proximal convoluted tubules (arrows) during $6^{\text {th }}$ week. (d): Necrotic renal tubules during $8^{\text {th }}$ week.

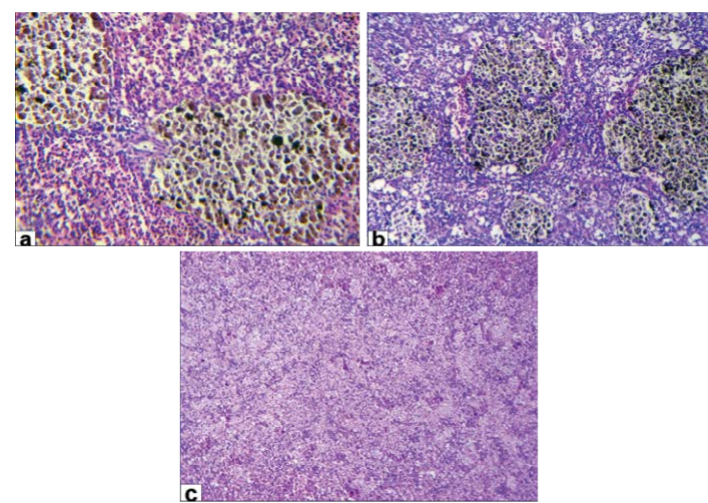

Figure 4: Photomicrograph of Spleen of $S$. galilaeus exposed to $2.83 \mathrm{mg} / \mathrm{L} \mathrm{CdCl}_{2}$ and staining by HE. (a): Enlargement and activation of MMCs (X250) during $2^{\text {nd }}$ week. (b): Enlargement and activation of MMCs where the melanophores appeared heavily loaded with dark brown melanin pigment (X250) during $4^{\text {th }}$ week.

(c): Necrosis and depletion of lymphocytes in white pulp (X160) during $6^{\text {th }}$ week

increases the distance across which waterborne pollutants must diffuse to reach the bloodstream [21]. These alterations have been reported for other species exposed to cadmium chloride [22,23]. The epithelial proliferation of secondary lamellae is one histological change found in fish exposed to cadmium and other pollutants [24,25]. The hyperplasia induced by any pollutant may be due to the simple response to cellular necrosis $[23,26]$. Moreover, Shaker et al. [27] reported that the epithelial hyperplasia is known as a protective and defense mechanism of fish gills. Necrosis of lamellar epithelial cells was evident. The exposure to pollutants leads to rupture of pilaster cells, which normally join the dorsal surface of secondary lamellae to the ventral one. The result will be dilatation of the lamellar capillary and pooling of the blood leading to the telangiectasis which is the characteristic pathological lesion of the gills associated with physical or chemical causes $[28,29]$.

The hepatopancreas is the site of detoxification of all types of toxins and chemicals. It is one of the organs most affected by water contaminants [30]. Microscopically, the detectable lesions in the hepatopancreas were congestion of the hepatic blood vessels, hepatic sinusoid and pancreatic acini. Moreover, there was acute cellular swelling of the hepatocytes where the primary mechanism of heavy metal cytotoxicity is the alteration of ion and non electrolyte transport and cell volume regulation, which finally lead to cell swelling $[21,31,32]$. In advanced cases, there was activation of MMCs. The circulating macrophage replete with particulate matter, home selectively on the melanomacrophage centers, hence the activation of the MMCs considered as a line of defense $[28,33]$. Moreover, there was necrosis of the hepatocytes and pancreatic acini [34]. Several studies had shown a variety of changes in the liver of $\mathrm{O}$. niloticus, resulting from exposure to different toxic chemicals $[35,36]$.

Upon the microscopical examination of the posterior kidney were in the form of congestion of large blood vessels and hemorrhage. Moreover, there was activation of melanomacrophage centre (MMCs) that play a role in the defense mechanism besides necrosis of renal tubular cells [33,37]. Eosinophilic staining hyaline droplets deposition within the cells of proximal tubules can often appear to replace necrotic renal epithelial and represent protein which has been reabsorbed from the glomerular filtrate. Since the renal tubular epithelium has its major function in the excretion of divalent ions, pollution with heavy metals such as cadmium is highly likely to affect these cells [38]. The histopathological changes observed due to cadmium toxicity were similar to other fishes due to heavy metal toxicity [39]. 
Citation: Tohamy HG, Shourbela RM (2016) Pathological Investigations on Galilee Tilapia (Sarotherodon galilaeus) Following Chronic Exposure to Cadmium Chloride. J Aquac Res Development 7: 446. doi: 10.4172/2155-9546.1000446

Page 4 of 4

Herein, the spleen showed enlargement and activation in melanomacrophage centre; the melanophores appeared heavily loaded with dark brown melanin pigment and lymphocytic cells necrosis that may be attributed to direct cytotoxic effect of cadmium chloride on lymphopoietic tissue, that may correlated with immune depressed $[28,33]$.

\section{Conclusion}

The histopathological changes on fish are a useful biomarker for understand the changes that occurring in different organs due to environmental pollution as well as constitutes a potential risk concern on human consumer's health so we recommend the authorities not to dispose the sewage and industrial wastes into surface water or at least to treat these effluents before its dumping.

\section{References}

1. Vutukuru SS, Suma C, Madhavi KR, Pauleena JS, Rao JV, et al. (2005) Studies on the development of potential biomarkers for rapid assessment of copper toxicity to freshwater fish using Esomus danricus as model. Int J Environ Res Public Health 2: 63-73.

2. Rauf A, Javed M, Ubaidullah M (2009) Heavy metal levels in three major carps (Catla catla, Labeo rohita, Cirrhina mrigala) from the river Ravi, Pakistan. Pak Vet J 29: 24-26.

3. Jagadeesan G, Jebanesan A, Mathivanan A (2001) In vivo recovery of organic constituents in gill tissue of Labo rohita after exposure to sublethal concentrations of mercury. J Exp Indian 3: 22-29.

4. Francis S, Mohan KG, Oommen V (2002) Influence of steroid hormones on plasma proteins in fresh water Tilapia O. mossambicus. Indian J Exper Biol 40: $1206-1208$.

5. Mendez-Armenta M, Rios C (2007) Cadmium neurotoxicity. Environ Toxicol Pharmacol 23: 350-358.

6. Friedman PA, Gesek FA (1994) Cadmium uptake by kidney distal convolute tubule cells. Toxicol Appl Pharmacol 128: 257-263.

7. Provias JP, Ackerley CA, Smith C, Becker LE (1994) Cadmium encephalopathy a report with elemental analysis and pathological findings. Acta Neuropathol 88: $583-586$

8. Novelli ELB, Lopes AM, Rodrigues A, Novelli FJ, Ribas BO (1999) Superoxide radical and nephrotoxic effect of cadmium exposure. Int $\mathrm{J}$ Environ Health Res 9: 109-116.

9. Popma TJ, Lovshin LL (1996) World prospects for commercial production of tilapia. Research and Development Series 41. International Center for Aquatic Environment, Department of Fisheries and Allied Aquaculture, Auburn University, Alabama, USA.

10. Kaoud A, Zaki M, El-Dahshan A, Saeid S, El ZH (2011) Amelioration the toxic effects of cadmium-exposure in Nile Tilapia (O. niloticus) by using Lemna gibba L. J Life Sci 8: 185-195.

11. Luo YJ, Shan D, Zhong H, Zhou Y, Chen WZ, et al. (2015) Sub-chronic effects of cadmium on the gonads, expressions of steroid hormones and sex-related genes in tilapia. Ecotox 24: 1-6.

12. Pavlov DF, Chuiko GM, Pavlov DD (2014) Growth of mozambique tilapia chronically exposed to cadmium, naphthalene, and DDVP. Inland Water Biol 7: $97-100$

13. Stephan CE (1977) Methods of calculation an LC $_{50}$ in: Aquatic toxicology and hazard evaluation, proceedings of the first Annual symposium on Aquatic Toxicology. 65-84.

14. Culling CF (1983) Handbook of histopathological \& histochemical staining techniques. (3rdedn), Butter Worth-London.

15. Eisler R (2000) Handbook of chemical risk assessment: Health hazards to humans, plants and animals. Metals. Lewis Publishers, New York.

16. Nordberg GF, Nogawa K, Nordberg M, Friedmann JM (2007) Cadmium. In Handbook on the Toxicology of Metals, Amsterdam: Elsevier.

17. ATSDR (2010) Agency for Toxic Substances and Disease Registry. 2008 Toxicological Profile for Cadmium.
18. Chung S (1983) Lethal effects of cadmium in Tropica. Bull Jpn Soc Sci 49 1565-1568.

19. Schwaiger J, Wanke U, Adam S, Pawert W, Honnen W, et al. (1997) The use of histopathological indicators to evaluate contaminant-related stress in fish. J Aquat Ecosystem Stress and Recov 6: 75-86.

20. Ferreira M, Antunes P, Gil O, Vale C, Reis-Henriques MA (2004) Organochlorine contaminants in flonder (Platichthys flesus) and mullet (Mugil cephatus) from Douro estuary and their use as sentinel species for environmental monitoring. Aquat Toxicol 69: 347-357.

21. Arellano JM, Storch V, Sarasquete C (1999) Histological changes and coppe accumulation in liver and gills of the senegales sole, Solea senegalensis. Ecotoxicol Environ Saf 44: 62-72.

22. Karlson-Norrgren L, Runn P, Haux C, Forlin L (1985) Cadmium-induced changes in gill morphology of zebra fish Brachydanio rerio (HamiltonBuchaman) and rainbow trout Salmo giardneri, Richardson. J Fish Biol 27: 81.

23. Thophon S, Kruatrachue M, Upatham ES, Pokethitiyook P, Sahaphong S, et al (2003) Histopathological alterations of white seabass, Lates calcarifer, in acute and subchronic cadmium exposure. Environ Pollut 121: 307-320.

24. Randi AS, Monserrat JM, Rodriguez EM, Romano LA (1996) Histopathological effects of cadmium on the gills of the freshwater fish, Macropsobrycon uruguayanae Eigenmann (Pisces, Atheinidae). J Fish Dis 19: 311-322.

25. Van den Heuvel MR, Power M, Richards J, MacKinnon M, Dixon DG (2000) Disease and gill lesions in yellow perch (Perca flavescens) exposed to oil sands mining-associated water. Ecotoxicol Environ Saf 46: 334-341.

26. Mallatt $J$ (1985) Fish gill structural changes induced by toxicants and other irritants: A statistical review. Can. J Fish Aquat Sci 42: 630-648.

27. Shaker IM, Ez-El-Rigal A, El Ghobashy H (2000) Effects of EDTA on reducing of copper toxicity in water and O. niloticus. Egy J Appl Sci 15: 119-131.

28. Roberts RJ (2001) Fish pathology. (3rdedn), Harcourt publishers limited.

29. Annabi A, Messaoudi I, Kerkeni A, Said K (2011) Cadmium accumulation and histological lesion in Mosquito fish (Gambusia affinis) tissues following acute and chronic exposure. Int J Environ Res 5: 745-756.

30. Camargo MM, Martinez CB (2007) Histopathology of gills, kidney and liver of a Neotropical fish caged in an urban stream. Neotrop Ichthyol 5: 327-336.

31. Austin B (1999) Effects of pollution on fresh health. J Appl Microbiol 85: 234-242.

32. Adam SM (2001) Biomarker bio-indicator response profiles of organisms can help differentiates between sources of anthropogenic stressors in aquatic ecosystems. J Biom 6: 33-44.

33. Costa PM, Caeiro S, Costa MH (2012) Multi-organ histological observations on juvenile Senegalese soles exposed to low concentrations of waterborne cadmium. Fish Physiol Biochem 39: 143-158.

34. Radhakrishnan MV, Hemalatha S (2010) Sublethal toxic effects of cadmium chloride to liver of freshwater fish Channa striatus. Am-Euras J Toxicol Sci 2: 54-56.

35. Visoottiviseth $P$, Thamamaruitkun $T$, Sahaphong $S$, Riengrojpitak $S$ Kruatrachue M (1999) Histopathological effects of triphenyltin hydroxide on liver, kidney and gill of Nile tilapia (O. niloticus). Appl Organometal Chem 13:749-763.

36. Figueiredo-Fernandes A, Fontaínhas-Fernandes A, Peixoto F, Rocha E, ReisHenriques MA (2006) Effect of paraquat on oxidative stress enzymes in tilapia (O. niloticus) at two levels of temperature. Pest Biochem Physiol 85: 97-103.

37. Singhal RN, Jain M (1997) Cadmium-induced changes in the histology of kidneys in common carp (Cyprinidae). B Environ Contam Tox 58: 456-462.

38. Schaperclaus W, Kulow H, Schreckenbach K (1991) Fish diseases. Oxonian Press, New Delhi.

39. Singhal RN, Wicklum D, Davies RW (1996) Undetectable accumulation of cadmium and its toxicity to nervous and non-nervous tissue of Nephelopsis obscura. Can J Zool 74: 184-190. 